\title{
A Study on the Effect of Employment Service Encounter with the Relationship Quality as a Mediator on the Word-of-mouth
}

\author{
Xicong Zheng* \\ Faculty of Business and Management \\ Xiamen Huaxia University \\ Xiamen, China 361024
}

\begin{abstract}
In the current employment market, with the rise of the job banks, members of the employment service systems are diversified and face fierce competition. In order to stand out in the job market, one must be committed to improving service quality and promptly establishing a positive reputation via social networks and customers' word of mouth. This study explores the effects of employment service encounters on service reputation by using relationship quality as an indicator. According to Blau's social exchange theory (1964), and the concept of relationship quality is divided into two types: quality of economic exchange-based and quality of social exchange-based relationships. An assessment of service quality was conducted using customer satisfaction, trust, and service commitment as assessment indicators. This study based on the general public who has more than three job-seekers in Taiwan, uses SPSS 20.0 and AMOS 20.0 to verify the analysis. Finally, it gives some policy recommendations accordingly.
\end{abstract}

Keywords-employment service; service encounter; relationship quality; word-of-mouth

\section{INTRODUCTION}

According to "World Employment and Social Outlook in 2017" published by the International Labor Organization (ILO), the report points out that since the global financial crisis, the global total unemployment is constantly rising. The European debt storm contributes to its worsening trend with the global unemployment in 2016 reaching 198 million, 28 million higher than that before the global crisis, and the global employment environment has been worsening as a lingering nightmare. After the Second World War, the ILO began to promote employment services in ahead, and the countries gradually plan the overall employment service policy with the integrated thinking of this program. And Taiwan region also complies with international trends to the implement three-in-one employment service process. This study explores the best service attitude and professional ability that the employment service staff should have at the key moment of interaction between job seekers and job match-making platform in order to give full play to the human resources and make manufacturers find suitable employees in the labor market in employment process, so that they can create price quality for customers and meet their job needs to create a positive word-of-mouth for their own job matching platform.

\section{LITERATURE REVIEW}

\section{A. The Definition of Employment Services and the Related Researches}

The concept of "Employment Service" was first used by the United Kingdom. After the Second World War, the British Government stated that it was "National Employment Service" and used up to now. Most countries in the world now use the term "Employment Service" (Chen Guojun, 1979).

The International Labor Organization (ILO) has its different view on employment services, of which the definition is as follows: "The government purposefully chooses to adopt the measure of intervening in job market for achieving the objectives of social equity and economic efficiency, including the provision of job opportunities and the promotion of the employ ability of disadvantaged labor in the market". For the unemployed or those about to be unemployed, the meaning of employment services is seen as a "Pushing Force" that can make the unemployed return to the labor market (Li Jianhong, 2008).

Weakening of the economy has led to a further rise in global unemployment, so more and more attention has been paid to employment services, and some scholars have begun to study the employment services and gradually clarify the concepts related to employment services. Cheng Zhiyue (2000) has a similar view that deems the meaning of employment services is engaging in placement between seeking talent and seeking job, and achieving the purpose of full employment through the provision of information, consultation service and friendly interaction. And Li Gengpei (2002) points out that the positive significance of employment services is strengthening the organization of employment market according to its unique professional function, effectively grasping the supply and demand of human resources, and quickly conveying professional information, so that job seekers won't fail in finding a job because of ill-informed professional information. Therefore,

*Associate Professor 
synthesizing the study of the above scholars, the main function of employment services is matching of supply and demand of the manpower, and promoting social progress and economic development.

\section{B. Overview of Employment Services Encounter}

"Employment Service Encounter" is a new term in this research, which means: "In order to enable the labor force in the labor market to be fully utilized and the manufacturer to find suitable employees, the moment of interaction between job seekers and job matching platform is an important key to influence the assessment of the satisfaction towards employment services from job seekers in the process of employment service."

1) Interpersonal employment services encounter: Before the network technology gets involved in employment services, traditional employment service encounter mostly relies on "personnel interaction". According to the results of the visit, it shows that the shortcoming is the unpopular service station, which leads to poor convenience and failure in providing real-time customized services, affecting the efficiency. Different service personnel have different service quality.

2) Technological employment services encounter: With the advent of the Internet technology era, the vigorous development of information technology has changed the interaction between employers and employees. The introduction of technology makes the concept of employment services encounter gradually change. Employment service procedure can be implemented accurately and efficiently through information technology and technological employment services encounter based on technology can replace interpersonal employment services encounter in some ways to a certain extent.

\section{Overview of Social Exchange Theory}

1) Social Exchange Theory: Homans (1958) first proposes social exchange theory at individual level, and then Blau (1964) applies the theory to practice, extends it to the general level and stresses the importance of norms, i.e., the social system and the exchange behavior between formal organizations.

Since Blau proposed the Social Exchange Theory, many researchers have adopted this theoretical view. Blau suggests that any exchange relationship in the organization can be divided into two types of transactions, namely Economic Exchange Relationship and Social Exchange Relationship. In the economic exchange relationship, the transaction type between people focuses on the assessment of immediate interests, while in the social exchange relationship, the establishment of the relationship between people has got out of the criteria of economic evaluation, and on the contrary the key to shaping the transaction relationship lies in the quality of interaction between each other.

2) Economic Exchange Viewpoint and Social Exchange: From the theoretical analysis in previous section, Blau has summed up two types of transactions. Geyskens and Steenkamp (2000) suggest that the satisfaction of both parties can be divided into two parts: economic satisfaction and social satisfaction. The term "economic satisfaction" means that "the assessment of economic output after cooperation between marketing channel members and channel partners, such as market share, sales, etc.", which is an economic exchange viewpoint; "social satisfaction" means "evaluation of Members of contact and interaction of channel members and trade partners", which is a social exchange viewpoint. This study, based on the study of Das and Teng (2001), discovers that the trust of both parties can be divided into two parts: ability trust and goodwill trust. It considers that "ability trust" refers that one party can complete an action according to the request and expectation of the other party, which can be used as a reference base for measuring the relationship quality of economic exchange viewpoint while "goodwill trust" means that one party trusts the other out of goodwill and it can be used as a reference base for measuring the relationship quality of social exchange viewpoint.

\section{The Definition of Relationship Quality and the Related Researches}

1) Definition of relationship quality: Levitt (1986) suggests that Relationship Quality is a combination of intangible value and can affect the outcome of future transactions between buyers and sellers. Crosby et al. (1990) first proposes a series of relations quality model to explain how the relationship quality that customer perceives affects the interaction between company and customer as shown in "Fig. 1". The study mentions that the professionalism of the service staff has a positive impact on the relationship quality. Thus we can see that the quality of service is a necessary condition for the relationship quality.

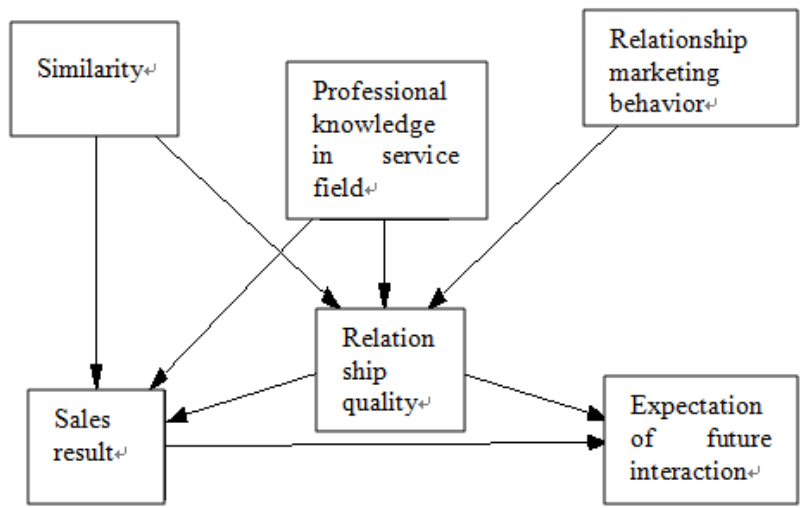

Fig. 1. Model of relationship quality.

The relationship quality is often defined as the quality of "relationship marketing". It is often cited as a guideline of the evaluation of customer relationship management quality in service in academic research. Although this study has no implication of marketing management, it is the only choice to choose its satisfaction, trust and commitment as the evaluation dimension of mediating effect. 
2) Relevant researches on relationship quality: Crosby et al. (1990) explores the "relationship between insurance salesmen and customers" from the perspective of social interpersonal relationships. He thinks the relationship quality that customer perceives will affect the opportunity of continuous interaction between customer and the salesman in the future, and this opportunity is subject to the similarity and expertise of salesman and customer as shown in "Fig. 2".

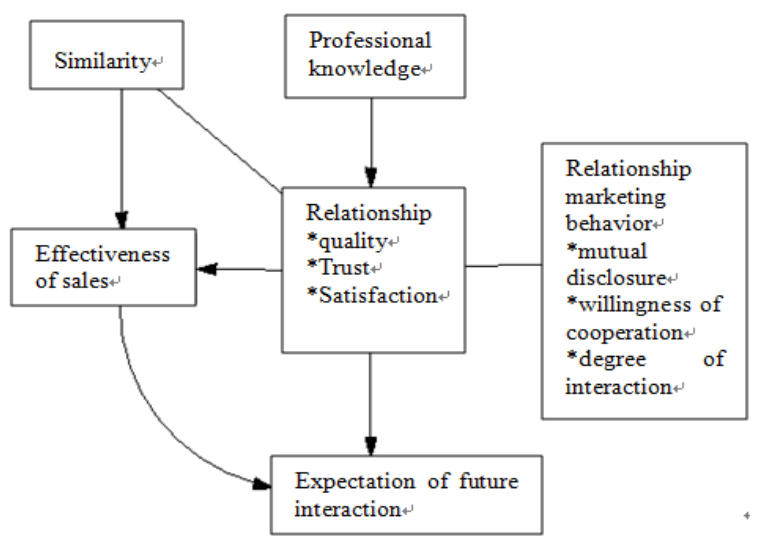

Fig. 2. Model of relationship quality of Crosby et al.

${ }^{\text {a. }}$ Data source: Crosby et al. (1990)

Smith (1998) explores the impact of similarity on relationship management and relationship quality taking purchasing staff and representatives of supplier business as the object of study. The result shows that the similarity between the buyers and sellers in the life stage, gender, cultural background, work attitude and personality will have different effects on the relationship investment, open communication and relationalism, and the similarity will indirectly affect the relationship quality through relationship management as shown in "Fig. 3".

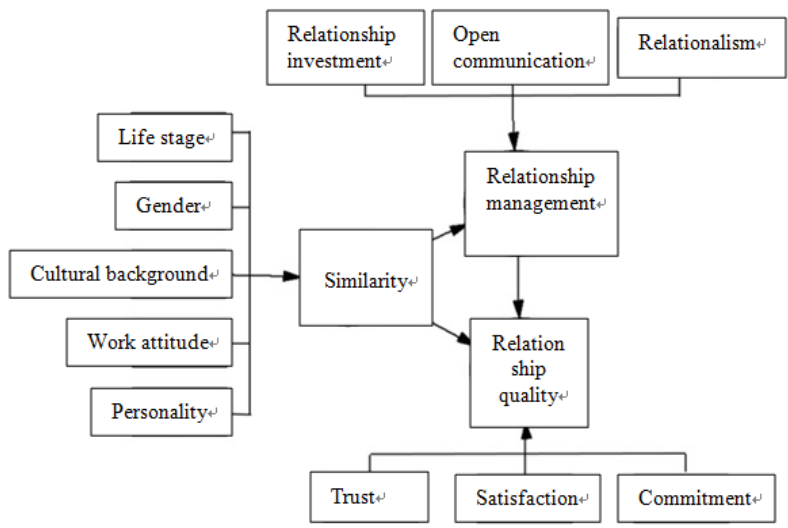

Fig. 3. Model of relationship quality of Smith.

Kim and Cha (2002) study the cause and effect of relationship quality by taking 12 five-star hotels in Seoul as samples. The result shows that customer orientation, relationship orientation and characteristics of service provider have a positive impact on the relationship quality.

Hennig-Thurau et al. (2002) propose an integrated model of the results of relationship marketing as shown in "Fig. 4".
The study aims to explore the relationship between the relationship benefit and the results of relationship marketing, and takes relationship quality as the intervening variable. The results show that confidence benefit and social benefits will affect loyalty, while the impact of special treatment benefits on loyalty is not significant; confidence benefit will affect satisfaction, but the impact of it on commitment is not significant; social benefit and special treatment benefits will affect the commitment, but they have no direct effect on satisfaction; satisfaction and commitment in the relationship quality have significant influence on the results of relationship marketing, and have good mediating effect in this model.

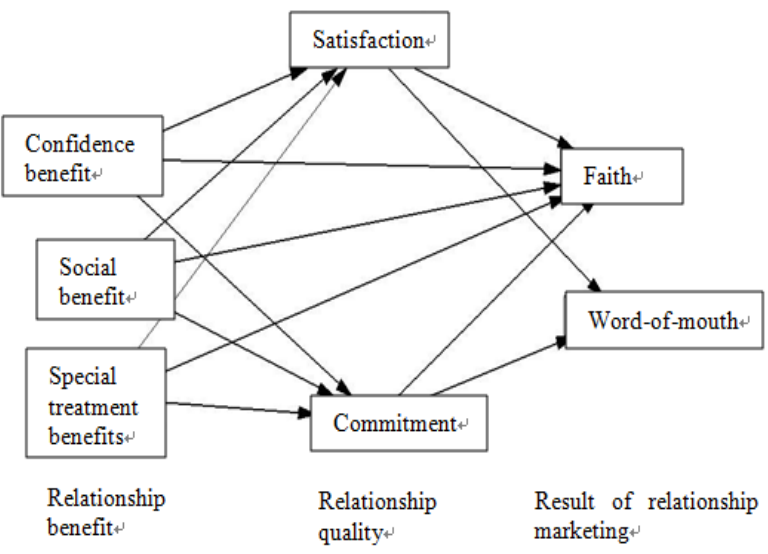

Fig. 4. integrated model of results of relationship marketing.

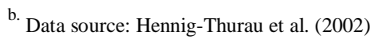

\section{E. Positive Word-of-mouth}

Word-of-mouth as a common social phenomenon widely exists in daily life and has been recognized as the most important source of communication among consumers (Derbaix and Vanhamme 2003). The term word-of-mouth firstly appeared in the literature that can be traced back to the "The Web of Word of Mouth" published by Fortbert in Fortune magazine in 1954. By 1955, Katz and Lazarsfeld's book "Personal Influence" had a very deep and insightful analysis of the concepts including interpersonal communication and individual influence. Since then, wordof-mouth has been cited by many researchers.

In 1957, Brooks publishes the Word of Mouth Advertising in Selling New Products in Journal of Marketing, which firstly discusses the phenomenon that word-of-mouth is in the consumer network, and then the term word-ofmouth has inseparable relationship with the words related to marketing such as "advertising", "Selling" and "Products". (Arndt, 1968; Woodside and Delozier, 1976; Holmes and Lett, 1977; Dodson and Mullerj, 1978)

Engel, Kegerreis, and Blackwell (1969) explore the word-of-mouth communication of innovators from the perspective of the mediator.

In 1983, Richins proposes the definition of exploratory study of negative word-of-mouth is telling at least one friend or family the unsatisfied using experience of a product. 
Many of the articles in 1990s explore a number of issues on marketing and consumer behavior based on the view of negative word-of-mouth (Singh, 1990; Smith and Vogt, 1995), so that the positive and negative word-of-Mouth issues become the mainstream in 1990s.

In recent years, with the progress of network technology, a variety of information platforms and network communication tools become increasingly diverse, serving as one of the main media where consumers receive the information and make the environment for discussion of phenomenon of word of mouth not only confined to the real world but expand to the vast network world, so the journal papers with electronic/ online WOM as the research topic played an important role in the past decade, making electronic/ online WOM gradually become another important research topic in the area of word-of-mouth.

\section{RESEARCH METHODS}

The main purpose of this study is to find out the perception of interpersonal and technological employment service encounter by taking the citizens who have experienced the traditional interpersonal employment service or who have experienced the technological job-seeking website in Taiwan as the object of study.

\section{A. Research Structure}

This study explores the perception of job seekers' on employment service, and tries to indirectly influence the word-of-mouth of receivers of employment service with the relationship quality between "economic exchange viewpoint" and "social exchange viewpoint" as intervening variable. At the same time, it makes sure if it has the disturbing effect variables through the perception of job seekers on the service encounter of different types of service encounter interaction. The research structure is as "Fig. 5":

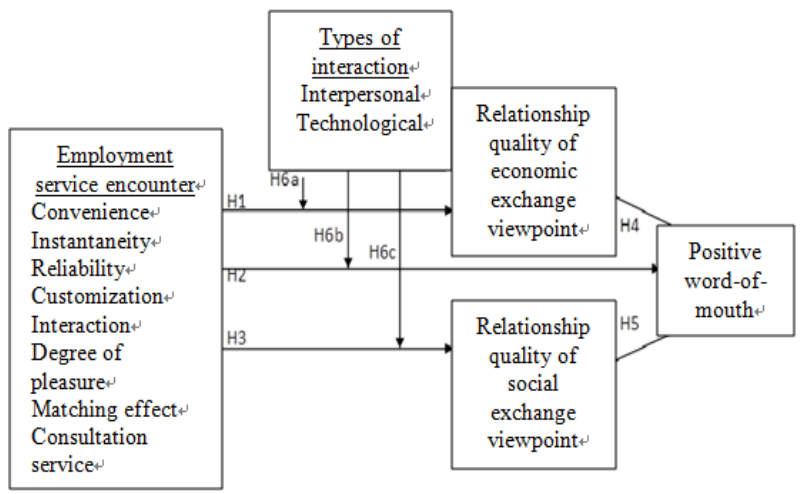

Fig. 5. Figure of research structure.

\section{B. Research Hypothesis and Inference}

This section plans to propose the following hypotheses based on the research structure:

H1: Does the employment service encounter have a positive impact on the relationship quality of the economic exchange viewpoint?
H2: Does the employment service encounter have a positive impact on the positive word-of-mouth?

H3: Does the employment service encounter have a positive impact on the relationship quality of the social exchange viewpoint?

H4: Does the relationship quality of the economic exchange viewpoint have a positive impact on the positive word-of-mouth?

H5: Does the relationship quality of social exchange viewpoint have a positive impact on positive word-of-mouth?

H6: What are the differences in the influence of employment service encounter of different types (interpersonal, technological) on the relationship quality and positive word-of-mouth?

H6a: What are the differences in the influence of employment service encounter of different types (interpersonal, technological) on the relationship quality of economic exchange viewpoint?

H6b: What are the differences in the influence of employment service encounter of different types (interpersonal, technological) on the positive word-of-mouth?

H6c: What are the differences in the influence of employment service encounter of different types (interpersonal, technological) on the relationship quality of social exchange viewpoint?

\section{Research Variables and Operational Definitions}

The dimensions of this study is divided into six parts: employment service encounter, relationship quality of social exchange viewpoints, relationship quality of economic exchange viewpoint, interpersonal employment service encounter, technological employment service encounter, and positive word-of-mouth. The research variables and operational definitions of this study are summarized as follows.

1) Employment services encounter: This study holds that employment service encounter can include eight influencing factors based on the relevant literature and empirical study, so this study uses facilitate, immediacy, reliability, customization, interactive relationship, pleasure, media results, and consultation service to measure the idea of employment service.

2) Relationship quality: This study believes relationship quality can include six characteristics based on the relevant literature and empirical researches and this study measures the construct of relationship quality by economic satisfaction, social satisfaction, competence trust, goodwill trust, calculated commitment, emotional commitment.

3) Different types of employment services encounter interaction

a) Interpersonal employment services encounter: This study defines interpersonal employment service encounter as: "The traditional employment service encounter mostly depends on the personnel interaction between job seekers 
and job matching platforms. The key moment of personnel interaction is the factor that creates the quality of employment services and can be used as the basis to measure the employment service experience." In addition, this study is based on the study of Solomon et al. (1985), which defines the characteristics of interpersonal service encounter as the two-way personnel interaction and difference of role play, which serves as the reference bases to measure the interpersonal employment service encounter from the perspective of social psychology.

b) Technological employment services encounter: This study defines technological employment service as "enhancing the effectiveness of employment services encounter through the involvement of technology, and the higher the degree of service technology job seekers use, the higher the degree of technological encounter." In addition, this study argues that both employees and customers can use technology to improve the satisfaction of service encounter as a basis for measuring the technological employment services encounter based on research of Bitner et al. (2000).

4) Positive word-of-mouth: This study defines the positive word-of-mouth as: "the behavior that job seekers have a positive assessment of the quality of employment services and recommend this job matching platform to others." In addition, this study refers to the research of Reichheld \& Sasser (1990), which argues that positive word-of-mouth publicity not only reduces business spending, but also successfully attracts new customers to create new profits, while negative word-of-mouth publicity will increase the advertising spending of business as the reference basis for measuring the positive word-of-mouth.

\section{Analytical Methods}

This study adopts statistical software to make analysis. In consideration of measurement of various variables and applicability of the statistical analysis tools, descriptive statistical analysis, the reliability of Cronbach's $\alpha$ examination questionnaire, examination validity of content validity, and structural equation model are used to make convergence validity analysis and verification hypothesis in this paper. After the collection and disposal of data, the statistical analysis method was used to analyze the valid questionnaires and illustrate the statistical results.

\section{RESEARCH RESULTS AND ANALYSIS}

\section{A. Reliability Analysis}

In this study, the Cronbach's $\alpha$ values of all dimensions are above 0.70 , indicating that the questions have a high degree of internal consistency and also representing the questionnaire of this study has a high degree of reliability as shown in "Table I".

TABLE I. RELIABILITY ANALYSIS OF ALL DiMENSIONS

\begin{tabular}{|c|c|c|c|c|c|}
\hline $\begin{array}{c}\text { Research } \\
\text { dimensions }\end{array}$ & $\begin{array}{l}\text { Research } \\
\text { variables }\end{array}$ & \multicolumn{2}{|c|}{$\begin{array}{c}\text { of } \\
\text { number } \\
\text { entries }\end{array}$} & $\begin{array}{l}\text { Reliability } \\
\text { of sub- } \\
\text { dimensions }\end{array}$ & $\begin{array}{c}\text { Overall } \\
\text { reliability of } \\
\text { dimension }\end{array}$ \\
\hline \multirow{8}{*}{$\begin{array}{c}\text { Employment } \\
\text { services } \\
\text { encounter }\end{array}$} & convenience & 3 & \multirow{8}{*}{24} & 0.841 & \multirow{8}{*}{0.968} \\
\hline & instantaneity & 3 & & 0.836 & \\
\hline & dependability & 3 & & 0.846 & \\
\hline & customization & 3 & & 0.836 & \\
\hline & interaction & 3 & & 0.856 & \\
\hline & $\begin{array}{l}\text { degree of } \\
\text { pleasure }\end{array}$ & 3 & & 0.885 & \\
\hline & $\begin{array}{c}\text { matching } \\
\text { effect }\end{array}$ & 3 & & 0.882 & \\
\hline & $\begin{array}{c}\text { quality of } \\
\text { consultation } \\
\text { service } \\
\end{array}$ & 3 & & 0.880 & \\
\hline \multirow{6}{*}{$\begin{array}{c}\text { Relationship } \\
\text { quality }\end{array}$} & $\begin{array}{c}\begin{array}{c}\text { Economic } \\
\text { satisfaction }\end{array} \\
\end{array}$ & 3 & \multirow{6}{*}{18} & 0.883 & \multirow{6}{*}{0.965} \\
\hline & $\begin{array}{c}\text { social } \\
\text { satisfaction }\end{array}$ & 3 & & 0.864 & \\
\hline & $\begin{array}{c}\text { competence } \\
\text { trust } \\
\end{array}$ & 3 & & 0.865 & \\
\hline & goodwill trust & 3 & & 0.887 & \\
\hline & $\begin{array}{c}\text { calculated } \\
\text { commitment }\end{array}$ & 3 & & 0.866 & \\
\hline & $\begin{array}{c}\text { emotional } \\
\text { commitment }\end{array}$ & 3 & & 0.890 & \\
\hline \multicolumn{2}{|c|}{ Positive word-of-mouth } & \multicolumn{2}{|l|}{6} & \multicolumn{2}{|l|}{0.935} \\
\hline
\end{tabular}

The theoretical model of this study has totally four dimensions, each of which has three questions to measure and verify the difference between each dimensions and the convergence validity. According to Hair et al. (1998), the load of standardized factors less than 0.7 are deleted as shown in "Table II". (1998)

TABLE II. TEST ON RELIABILITY AND CONVERGENCE VALIDITy OF MEASUREMENT OF Dimensions OF THEORETICAL MODEL

\begin{tabular}{|c|c|c|c|c|c|c|c|c|}
\hline \multirow{2}{*}{ Dimension } & \multirow{2}{*}{ Measurement item } & \multicolumn{5}{|c|}{ Estimated value of model parameter } & \multicolumn{2}{|c|}{$\begin{array}{c}\text { Convergent } \\
\text { validity }\end{array}$} \\
\hline & & $\begin{array}{l}\text { Non-standardized } \\
\text { factor load }\end{array}$ & $\begin{array}{l}\text { Standard } \\
\text { error }\end{array}$ & $\begin{array}{c}\mathbf{T} \\
\text { Value }\end{array}$ & $\begin{array}{l}\text { Standardized } \\
\text { factor load }\end{array}$ & $\begin{array}{c}\text { Cronbach's } \\
\alpha\end{array}$ & $\mathbf{C R}$ & AVE \\
\hline \multirow{8}{*}{$\begin{array}{c}\text { Employment } \\
\text { service } \\
\text { encounter }\end{array}$} & convenience & 1 & & & 0.702 & \multirow{8}{*}{0.939} & \multirow{8}{*}{$\begin{array}{l}0.93 \\
4\end{array}$} & \multirow{8}{*}{0.641} \\
\hline & instantaneity & 1.025 & 0.048 & 21.375 & 0.787 & & & \\
\hline & dependability & 1.055 & 0.048 & 22.19 & 0.818 & & & \\
\hline & customization & 1.044 & 0.048 & 21.821 & 0.804 & & & \\
\hline & interaction & 1.03 & 0.047 & 22.077 & 0.813 & & & \\
\hline & degree of pleasure & 1.129 & 0.05 & 22.354 & 0.824 & & & \\
\hline & matching effect & 1.13 & 0.05 & 22.835 & 0.842 & & & \\
\hline & quality of consultation service & 1.043 & 0.048 & 21.918 & 0.807 & & & \\
\hline \multirow{3}{*}{$\begin{array}{c}\text { Economic } \\
\text { relationship } \\
\text { quality }\end{array}$} & Economic satisfaction & 1 & & & 0.853 & \multirow{3}{*}{0.869} & \multirow{3}{*}{$\begin{array}{l}0.87 \\
4\end{array}$} & \multirow{3}{*}{0.698} \\
\hline & competence trust & 1.024 & 0.031 & 33.33 & 0.869 & & & \\
\hline & calculated commitment & 0.976 & 0.035 & 27.725 & 0.782 & & & \\
\hline
\end{tabular}




\begin{tabular}{|c|c|c|c|c|c|c|c|c|}
\hline \multirow{2}{*}{ Dimension } & \multirow{2}{*}{ Measurement item } & \multicolumn{5}{|c|}{ Estimated value of model parameter } & \multicolumn{2}{|c|}{$\begin{array}{c}\text { Convergent } \\
\text { validity }\end{array}$} \\
\hline & & $\begin{array}{c}\text { Non-standardized } \\
\text { factor load }\end{array}$ & $\begin{array}{c}\text { Standard } \\
\text { error }\end{array}$ & $\begin{array}{c}T \\
\text { Value }\end{array}$ & $\begin{array}{c}\text { Standardized } \\
\text { factor load }\end{array}$ & $\begin{array}{c}\text { Cronbach's } \\
\alpha\end{array}$ & CR & AVE \\
\hline \multirow{3}{*}{$\begin{array}{c}\text { Society } \\
\text { Relationship } \\
\text { quality }\end{array}$} & social satisfaction & 1 & & & 0.86 & \multirow{3}{*}{0.859} & \multirow{3}{*}{$\begin{array}{l}0.86 \\
4\end{array}$} & \multirow{3}{*}{0.679} \\
\hline & goodwill trust & 1.011 & 0.033 & 30.401 & 0.824 & & & \\
\hline & emotional commitment & 1.038 & 0.037 & 28.07 & 0.787 & & & \\
\hline \multirow{5}{*}{$\begin{array}{l}\text { Positive word-of- } \\
\text { mouth }\end{array}$} & 01 & 1 & & & 0.829 & \multirow{5}{*}{0.911} & \multirow{5}{*}{$\begin{array}{l}0.91 \\
2\end{array}$} & \multirow{5}{*}{0.674} \\
\hline & 02 & 0.992 & 0.036 & 27.92 & 0.834 & & & \\
\hline & 03 & 0.974 & 0.035 & 27.975 & 0.835 & & & \\
\hline & 04 & 0.941 & 0.034 & 27.503 & 0.826 & & & \\
\hline & 05 & 0.943 & 0.037 & 25.337 & 0.78 & & & \\
\hline
\end{tabular}

Fit index: $\mathrm{GFI}=0.872 \mathrm{AGFI}=0.833 \mathrm{NFI}=0.924 \mathrm{CFI}=0.934 \mathrm{RMSEA}=0.086$

In terms of validity, the average variance extraction (AVE) of the hypothesis of this study is higher than the limited value of 0.5 that Fornell and Larcker (1981) suggested, which has good convergence validity. In this study, Pearson correlation analysis is used as the correlation test of research hypothesis, so we can see that there is a positive correlation between the theoretical model constructs of this study in "Table III".

TABLE III. TEST ON THE DISCRIMINANT VALIDITY OF THE THEORETICAL MODEL CONSTRUCTS

\begin{tabular}{|c|l|l|l|l|}
\hline & $\begin{array}{c}\text { Employment } \\
\text { services } \\
\text { encounter }\end{array}$ & $\begin{array}{c}\text { Economic } \\
\text { relationship } \\
\text { quality }\end{array}$ & $\begin{array}{c}\text { Social } \\
\text { relationship } \\
\text { quality }\end{array}$ & $\begin{array}{c}\text { Positive } \\
\text { word-of- } \\
\text { mouth }\end{array}$ \\
\hline $\begin{array}{c}\text { Employment } \\
\text { services encounter }\end{array}$ & 0.801 & & & \\
\hline $\begin{array}{c}\text { Economic } \\
\text { relationship } \\
\text { quality }\end{array}$ & 0.689 & 0.835 & 0.824 & \\
\hline $\begin{array}{c}\text { Social relationship } \\
\text { quality }\end{array}$ & 0.672 & 0.816 & 0.698 & 0.820 \\
\hline $\begin{array}{c}\text { Positive word-of- } \\
\text { mouth }\end{array}$ & 0.577 & 0.673 & & \\
\hline
\end{tabular}

d. Note: the diagonal is the square root extracted from average variation and the rest are the correlation coefficient. ${ }^{*} \mathrm{p}<0.05, \quad{ }^{* *} \mathrm{p}<0.01, \quad{ }^{* * *} \mathrm{p}<0.001$
The theoretical model of this study as shown in "Fig. 6" includes four parts: employment service encounter, quality relationship of economic exchange view and social exchange view, and positive word-of-mouth. AMOS 20.0 is used to make structural model analysis to verify each research hypothesis, and the results show the observation sample is well fit for the theoretical model. The results of the path analysis show that the employment service encounter has a significant positive impact on the relationship quality of the economic exchange viewpoint with the standardized structural coefficient 0.990, i.e., H1 is valid. Employment service encounter has no significant effect on the positive word-of-mouth with the standardized structure coefficient 0.312 , so $\mathrm{H} 2$ is invalid; employment service encounter has a positive effect on the relationship quality of social exchange viewpoint with the standardized structure coefficient 0.968 , which indicates that $\mathrm{H} 3$ is valid; the relationship quality of economic exchange viewpoint has no impact on positive word-of-mouth with the standardized structure coefficient 0.381, which means $\mathrm{H} 4$ is invalid; relationship quality of social exchange viewpoint has a positive impact on the positive word-of-mouth with the standardized structure coefficient 0.798 . That is to say, H5 is valid as shown in "Table IV".

TABLE IV. Empirical Results of OVERALl TheORETICAL Model

\begin{tabular}{|c|c|c|c|c|c|c|}
\hline \multirow{2}{*}{\multicolumn{2}{|c|}{$\begin{array}{l}\text { Cause and effect } \\
\text { Approach }\end{array}$}} & \multirow[b]{2}{*}{ Hypothesis } & \multicolumn{4}{|c|}{ Theoretical model } \\
\hline & & & $\begin{array}{c}\text { Non-standardized } \\
\text { factor load }\end{array}$ & Standard error S.E & T-value (CR) & $\begin{array}{c}\text { Standardized } \\
\text { structure coefficients }\end{array}$ \\
\hline \multicolumn{2}{|c|}{$\begin{array}{c}\text { Employment service encounter } \rightarrow \text { Economic } \\
\text { exchange viewpoint }\end{array}$} & $\mathrm{H} 1$ & 1.168 & 0.052 & 22.509 & 0.99 \\
\hline \multicolumn{2}{|c|}{$\begin{array}{c}\text { Employment services encounter } \rightarrow \text { positive } \\
\text { word-of-mouth }\end{array}$} & $\mathrm{H} 2$ & 0.419 & 1.033 & 0.405 & 0.312 \\
\hline \multicolumn{2}{|c|}{$\begin{array}{c}\text { Employment service } \\
\text { encounter } \rightarrow \text { relationship quality of social } \\
\text { exchange viewpoint }\end{array}$} & $\mathrm{H} 3$ & 1.132 & 0.052 & 21.935 & 0.968 \\
\hline \multicolumn{2}{|c|}{$\begin{array}{c}\text { Relationship quality of economic exchange } \\
\text { viewpoint } \rightarrow \text { positive word-of-mouth }\end{array}$} & H4 & -0.434 & 0.764 & -0.568 & -0.381 \\
\hline \multicolumn{2}{|c|}{$\begin{array}{l}\text { Relationship quality of social exchange } \\
\text { viewpoint } \rightarrow \text { positive word-of-mouth }\end{array}$} & H5 & 0.917 & 0.298 & 3.075 & 0.798 \\
\hline Fit index & \multicolumn{2}{|c|}{ Judgment value } & Fitted value & Fitting status & \multicolumn{2}{|c|}{ Reference source } \\
\hline GFI & \multicolumn{2}{|l|}{$>0.8$} & 0.847 & good & \multicolumn{2}{|c|}{ Seyal et al. (2002) } \\
\hline$A G F I$ & \multicolumn{2}{|l|}{$>0.8$} & 0.802 & good & \multicolumn{2}{|c|}{ Scott (1994) } \\
\hline$N F I$ & \multicolumn{2}{|l|}{$>0.8$} & 0.908 & good & \multicolumn{2}{|c|}{ Bentler \& Bonett (1989) } \\
\hline CFI & \multicolumn{2}{|l|}{$>0.9$} & 0.918 & good & \multicolumn{2}{|c|}{ Bentler \&Bonett（1989） } \\
\hline RMSEA & \multicolumn{2}{|l|}{$<0.08$} & 0.096 & ordinary fitting & \multicolumn{2}{|c|}{ Hair et al. (1992) } \\
\hline
\end{tabular}




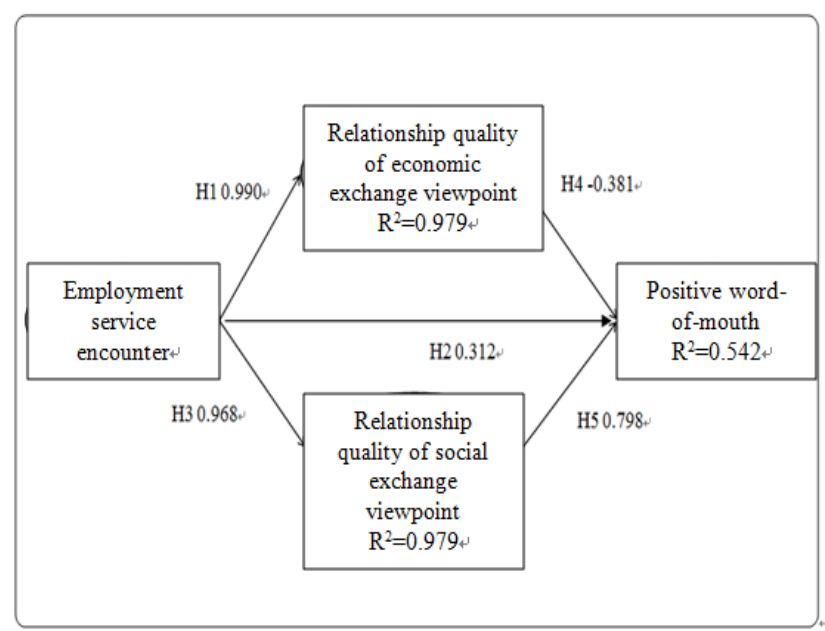

In order to explore if different types of service encounter have different effects on the paths of overall theoretical model, this study divides the subjects into "technological type" and "interpersonal type" to explore the difference of different moral awareness in each influence path by using Amos20.0 to calculate the critical ratio between each groups (Critical Ratios for Differences between Parameters). When the absolute value of the statistics between groups is greater than 1.96, it represents that under the the significant level of 0.05 , the coefficient values of the two groups are significantly different. The empirical results show that the two groups of "technological type" and "interpersonal type" have no interference effect in the paths of $\mathrm{H} 1, \mathrm{H} 2, \mathrm{H} 3, \mathrm{H} 4$, and $\mathrm{H} 5$ as shown in "Table V".

Fig. 6. Empirical results of theoretical model.

TABLE V. INTERFERENCE EFFECTS OF DIFFERENT EMPLOYMENT SERVICES ENCOUNTER

\begin{tabular}{|c|c|c|c|c|c|c|}
\hline \multirow{3}{*}{ Approach } & \multirow{3}{*}{ Approach } & \multirow{3}{*}{ Type } & \multirow{3}{*}{ Sample } & \multicolumn{3}{|c|}{ Multi-sample test } \\
\hline & & & & \multirow{2}{*}{$\begin{array}{l}\text { Standardized structure } \\
\text { coefficients }\end{array}$} & \multicolumn{2}{|c|}{$\begin{array}{c}\text { Differential test value } \\
\text { Paired parameter comparison }\end{array}$} \\
\hline & & & & & Technological & Interpersonal \\
\hline \multirow{2}{*}{$\begin{array}{c}\text { Employment service encounter } \rightarrow \text { relationship } \\
\text { quality of economic exchange viewpoint }\end{array}$} & \multirow{2}{*}{ H1 } & technological & 431 & 0.999 & 0 & \\
\hline & & interpersonal & 365 & 0.981 & 0.094 & 0 \\
\hline \multirow{2}{*}{$\begin{array}{c}\text { Employment services encounter } \rightarrow \text { positive } \\
\text { word-of-mouth }\end{array}$} & \multirow{2}{*}{$\mathrm{H} 2$} & technological & 431 & 0.962 & 0 & \\
\hline & & interpersonal & 365 & 0.973 & -0.111 & 0 \\
\hline \multirow{2}{*}{$\begin{array}{c}\text { Employment service encounter } \rightarrow \text { relationship } \\
\text { quality of social exchange viewpoint }\end{array}$} & \multirow{2}{*}{$\mathrm{H} 3$} & technological & 431 & 3.486 & 0 & \\
\hline & & interpersonal & 365 & 0.308 & 1.331 & 0 \\
\hline \multirow{2}{*}{$\begin{array}{l}\text { Relationship quality of economic exchange } \\
\text { viewpoint } \rightarrow \text { positive word-of-mouth }\end{array}$} & \multirow{2}{*}{$\mathrm{H} 4$} & technological & 431 & -3.549 & 0 & \\
\hline & & interpersonal & 365 & -0.454 & 0.111 & 0 \\
\hline \multirow{2}{*}{$\begin{array}{l}\text { Relationship quality of social exchange } \\
\text { viewpoint } \rightarrow \text { positive word-of-mouth }\end{array}$} & \multirow{2}{*}{ H5 } & technological & 431 & 0.837 & 0 & \\
\hline & & interpersonal & 365 & 0810 & -0.228 & 0 \\
\hline
\end{tabular}

In order to further test the mediating effect of "relationship quality of economic exchange viewpoint" and the "relationship quality of social exchange viewpoint", Mackinnon (2008) finds that the Sobel test is the best estimate of the standard error of mediating effect. It can be known from the Sobel test that "Service encounter" can have an effect on the "positive word-of-mouth" indirectly through the "relationship quality of social exchange viewpoint". $\mathrm{Z}=$ $3.046, p<0.01$, the mediating effect of "relationship quality of the social exchange viewpoint" exists significantly as shown in "Table VI".

TABLE VI. MEDiATing EFFECT OF PERCEIVED Risk (SOBEL TEST)

\begin{tabular}{|c|c|c|c|c|c|}
\hline Approach & $\begin{array}{c}\text { Non-standardized } \\
\text { Structure coefficients }\end{array}$ & Standard error SE & $\mathbf{Z}$ & Significant level & $\begin{array}{c}\text { Verification } \\
\text { result } \\
\end{array}$ \\
\hline $\begin{array}{c}\text { Employment service encounter } \rightarrow \text { relationship } \\
\text { quality of economic exchange viewpoint }\end{array}$ & 1.168 & 0.052 & \multirow{2}{*}{-0.567} & \multirow{2}{*}{0.570} & \multirow{2}{*}{$\begin{array}{l}\text { not } \\
\text { significant }\end{array}$} \\
\hline $\begin{array}{c}\text { Relationship quality of economic exchange } \\
\text { viewpoint } \rightarrow \text { positive word-of-mouth }\end{array}$ & -0.434 & 0.764 & & & \\
\hline $\begin{array}{c}\text { Employment service encounter } \rightarrow \text { relationship } \\
\text { quality of social exchange viewpoint }\end{array}$ & 1.132 & 0.052 & \multirow{2}{*}{3.046} & \multirow{2}{*}{0.002} & \multirow{2}{*}{ significant } \\
\hline $\begin{array}{l}\text { Relationship quality of social exchange } \\
\text { viewpoint } \rightarrow \text { positive word-of-mouth }\end{array}$ & 0.917 & 0.298 & & & \\
\hline
\end{tabular}

\section{B. Correlation Analysis of the Variables in the Research}

This study firstly makes Pearson correlation analysis to the factors of the research to see if there is significant correlation between the variables. However, the correlation coefficient can only determine the intensity of the relationship between the variables, instead of determining whether there is a causal relationship with each other.

From the relevant analysis table of "Table VII", it can be found that there is significant positive correlation between employment service encounter, relationship quality of economic exchange viewpoint, relationship quality of social 
TABLE VII. CORRELATION ANALYSIS TABLE OF ALL DIMENSIONS

\begin{tabular}{|c|c|c|c|c|}
\hline & $\begin{array}{c}\begin{array}{c}\text { Employment services } \\
\text { encounter }\end{array} \\
\end{array}$ & $\begin{array}{c}\text { Economic exchange viewpoint } \\
\text { Relationship quality }\end{array}$ & $\begin{array}{c}\text { Social exchange viewpoint } \\
\text { Relationship quality }\end{array}$ & $\begin{array}{c}\text { Positive word- } \\
\text { of-mouth }\end{array}$ \\
\hline Employment services encounter & 1 & & & \\
\hline $\begin{array}{c}\text { Relationship quality of economic } \\
\text { exchange viewpoint }\end{array}$ & $0.879 * *$ & 1 & & \\
\hline $\begin{array}{c}\text { Relationship quality of social } \\
\text { exchange viewpoint }\end{array}$ & $0.848 * *$ & $0.918 * *$ & 1 & \\
\hline Positive word-of-mouth & $0.770 * *$ & $0.820 * *$ & $0.829 * *$ & 1 \\
\hline
\end{tabular}

\section{Regression Analysis}

As can be seen from the results in "Table VIII", in the sub-dimensions of employment services encounter of job matching platform, "reliability", "customization", "instantaneity", "degree of pleasure", "matching effect", and "convenience" have a positive and significant impact on the "relationship quality of economic exchange viewpoint", but the "quality of consultation service" and "interaction" have no significant effect on the relationship quality of economic exchange viewpoint.

TABLE VIII. REGRESSION ANALYSIS OF THE IMPACT OF EMPLOYMENT SERVICE ENCOUNTER ON ECONOMIC EXCHANGE VIEWPOINT

\begin{tabular}{|c|c|c|c|c|}
\hline \multirow{2}{*}{\multicolumn{2}{|c|}{ Multiple regression model }} & \multicolumn{3}{|c|}{$\begin{array}{c}\text { Dependent variable: } \\
\text { relationship quality of } \\
\text { economic exchange } \\
\text { viewpoint }\end{array}$} \\
\hline & & $\beta$ value & $\begin{array}{c}\mathbf{T} \\
\text { value }\end{array}$ & $\begin{array}{c}\mathbf{P} \\
\text { value }\end{array}$ \\
\hline \multirow{8}{*}{$\begin{array}{l}\text { Independent } \\
\text { variable: } \\
\text { employment } \\
\text { services } \\
\text { encounter }\end{array}$} & convenience & $0.269 * *$ & 10.277 & 0.000 \\
\hline & instantaneity & $0.087 * *$ & 3.063 & 0.002 \\
\hline & dependability & $0.099 * *$ & 3.542 & 0.000 \\
\hline & customization & $0.080 * *$ & 2.923 & 0.004 \\
\hline & interaction & 0.042 & 1.515 & 0.130 \\
\hline & $\begin{array}{l}\text { degree of } \\
\text { pleasure }\end{array}$ & $0.124 * *$ & 4.386 & 0.000 \\
\hline & $\begin{array}{l}\text { matching } \\
\text { effect }\end{array}$ & $0.300 * *$ & 10.684 & 0.000 \\
\hline & $\begin{array}{l}\text { quality of } \\
\text { consultation } \\
\text { service }\end{array}$ & 0.019 & 0.820 & 0.412 \\
\hline$R 2$ & \multicolumn{4}{|l|}{0.804} \\
\hline $\operatorname{Adj} R 2$ & \multicolumn{4}{|l|}{0.803} \\
\hline F-value & \multicolumn{4}{|l|}{$458.965 * *$} \\
\hline
\end{tabular}

From the results table in "Table IX", it can be seen that in the sub-dimensions of employment services encounter of job matching platform, "reliability", "interaction", "degree of pleasure", "matching effect", and "quality of consultation service" have a positive and significant impact on the "relationship quality of social exchange viewpoint", but "convenience", "instantaneity" and "customization" have no significant effect on the relationship quality of social exchange viewpoint.

TABLE IX. REGRESSION ANALYSIS OF THE IMPACT OF EMPLOYMENT SERVICE ENCOUNTER ON THE RELATIONSHIP QUALITY OF SOCIAL EXCHANGE VIEWPOINT

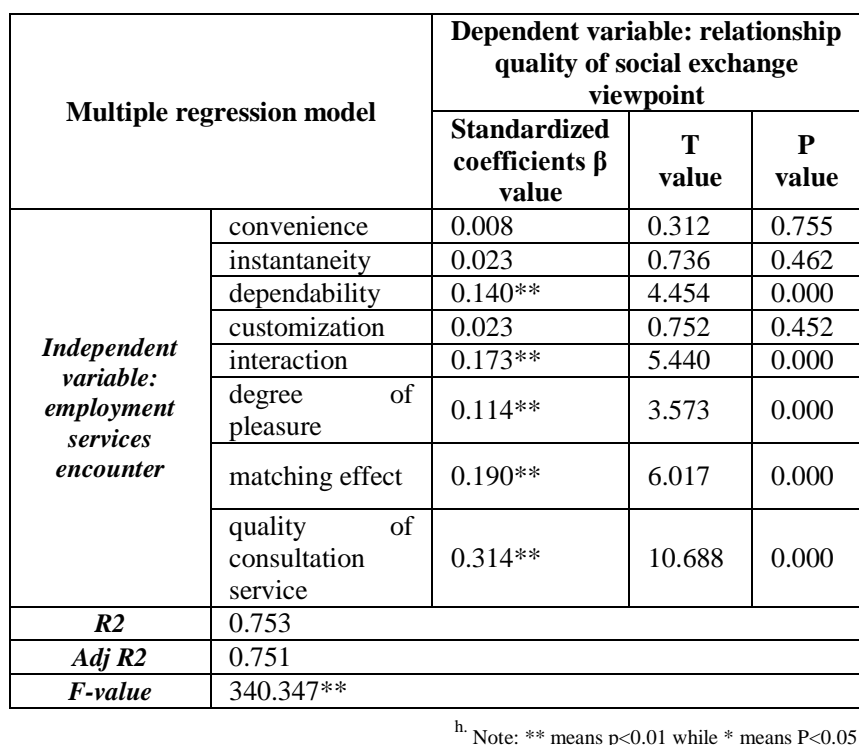

As can be seen from the results table in "Table X", in the sub-dimensions of social exchange viewpoint of the job matching platform, "social satisfaction", "goodwill trust" and "emotional commitment" have a significant positive impact on the "positive word-of-mouth".

TABLE X. REGRESSION ANALYSIS OF IMPACT OF RELATIONSHIP QUALITY OF SOCIAL EXCHANGE VIEWPOINT ON THE POSITIVE WORD-OF-MOUTH

\begin{tabular}{|c|c|c|c|c|c|}
\hline \multirow{2}{*}{\multicolumn{3}{|c|}{ Multiple regression model }} & \multicolumn{3}{|c|}{ Dependent variable: positive word-of-mouth } \\
\hline & & & \multirow{2}{*}{$\begin{array}{l}\text { Standardized coefficients } \boldsymbol{\beta} \text { value } \\
0.226^{* *}\end{array}$} & \multirow{2}{*}{$\frac{\text { T value }}{7.502}$} & \multirow{2}{*}{$\frac{\text { P value }}{0.000}$} \\
\hline \multirow{3}{*}{ Independent variable } & \multirow{3}{*}{$\begin{array}{l}\text { relationship quality } \\
\text { of social exchange } \\
\text { viewpoint }\end{array}$} & social satisfaction & & & \\
\hline & & goodwill trust & $0.175^{* *} *$ & 5.782 & 0.000 \\
\hline & & emotional commitment & $0.525 * *$ & 19.798 & 0.000 \\
\hline$R 2$ & \multicolumn{5}{|l|}{0.707} \\
\hline $\operatorname{Adj} \mathbf{R 2}$ & \multicolumn{5}{|l|}{0.706} \\
\hline F-value & \multicolumn{5}{|l|}{$723.256 * *$} \\
\hline
\end{tabular}




\section{Results of this Research}

Based on the above analysis, the results are summarized as follows "Table XI":

TABLE XI. Test Results of Hypothesis of Relationship Quality of ECONOMIC EXCHANGe ViewPoint in EMPLOYMENT SERVICE ENCOUNTER

\begin{tabular}{|c|l|l|l|l|}
\hline $\begin{array}{c}\text { Dimension of independent } \\
\text { variable }\end{array}$ & \multicolumn{2}{|c|}{$\begin{array}{c}\text { Dimension of dependent } \\
\text { variable }\end{array}$} & $\begin{array}{l}\text { Research } \\
\text { hypothesis }\end{array}$ & $\begin{array}{l}\text { Content of hypothesis } \\
\text { analysis }\end{array}$ \\
\hline convenience & $\begin{array}{l}\text { relationship quality of } \\
\text { economic exchange viewpoint }\end{array}$ & $\mathrm{H} 1-1$ & $\begin{array}{l}\text { Does convenience have a positive impact on the } \\
\text { relationship quality of the economic exchange viewpoint? }\end{array}$ & yes \\
\hline instantaneity & $\begin{array}{l}\text { relationship quality of } \\
\text { economic exchange viewpoint }\end{array}$ & $\mathrm{H} 1-2$ & $\begin{array}{l}\text { Does instantaneity have a positive impact on the } \\
\text { relationship quality of the economic exchange viewpoint? }\end{array}$ & yes \\
\hline dependability & $\begin{array}{l}\text { relationship quality of } \\
\text { economic exchange viewpoint }\end{array}$ & $\mathrm{H} 1-3$ & $\begin{array}{l}\text { Does dependability have a positive impact on the } \\
\text { relationship quality of the economic exchange viewpoint? }\end{array}$ & yes \\
\hline customization & $\begin{array}{l}\text { relationship quality of } \\
\text { economic exchange viewpoint }\end{array}$ & $\mathrm{H} 1-4$ & $\begin{array}{l}\text { Does customization have a positive impact on the } \\
\text { relationship quality of the economic exchange viewpoint? }\end{array}$ & yes \\
\hline interaction & $\begin{array}{l}\text { relationship quality of } \\
\text { economic exchange viewpoint }\end{array}$ & $\mathrm{H} 1-5$ & $\begin{array}{l}\text { Does interaction have a positive impact on the } \\
\text { relationship quality of the economic exchange viewpoint? }\end{array}$ & no \\
\hline degree of pleasure & $\begin{array}{l}\text { relationship quality of } \\
\text { economic exchange viewpoint }\end{array}$ & H1-6 & $\begin{array}{l}\text { Does degree of pleasure have a positive impact on the } \\
\text { relationship quality of the economic exchange viewpoint? }\end{array}$ & yes \\
\hline matching effect & $\begin{array}{l}\text { relationship quality of } \\
\text { economic exchange viewpoint }\end{array}$ & H1-7 & $\begin{array}{l}\text { Does matching effect have a positive impact on the } \\
\text { relationship quality of the economic exchange viewpoint? }\end{array}$ & yes \\
\hline quality of consultation service & $\begin{array}{l}\text { relationship quality of } \\
\text { economic exchange viewpoint }\end{array}$ & H1-8 & $\begin{array}{l}\text { Does quality of consultation service have a positive } \\
\text { impact on the relationship quality of the economic } \\
\text { exchange viewpoint? no }\end{array}$ & no \\
\hline
\end{tabular}

It can be seen from the regression analysis that the six dimensions of employment service encounter has a positive and significant impact on relationship quality of economic exchange viewpoint, which shows that in the process of employment service encounter of job matching platform, when the above perception provided by job matching platform for the users increases, it will promote the users of platform to generate higher economic relationship quality to job matching platform, which is consistent with the assumptions of this study. However, quality of consultation service and interaction has no significant impact on the relationship quality of economic exchange viewpoint in employment service encounter, so $\mathrm{H} 1-5$ and $\mathrm{H} 1-8$ are invalid.

TABLE XII. TeSt RESUlts of Hypothesis of RELATIONSHIP QUALITY OF SOCIAL EXCHANGE VIEWPOINT IN EMPLOYMENT SERVICE ENCOUNTER

\begin{tabular}{|c|c|c|c|c|}
\hline $\begin{array}{c}\text { Dimension of } \\
\text { independent variable }\end{array}$ & $\begin{array}{l}\text { Dimension of dependent } \\
\text { variable }\end{array}$ & $\begin{array}{c}\text { Research } \\
\text { hypothesis }\end{array}$ & Content of hypothesis & $\begin{array}{l}\text { Research } \\
\text { analysis }\end{array}$ \\
\hline convenience & $\begin{array}{l}\text { relationship quality of social } \\
\text { exchange viewpoint }\end{array}$ & H3-1 & $\begin{array}{l}\text { Does convenience have a positive impact on the relationship } \\
\text { quality of the social exchange viewpoint? }\end{array}$ & no \\
\hline instantaneity & $\begin{array}{l}\text { relationship quality of social } \\
\text { exchange viewpoint }\end{array}$ & H3-2 & $\begin{array}{l}\text { Does instantaneity have a positive impact on the relationship } \\
\text { quality of the social exchange viewpoint? }\end{array}$ & no \\
\hline dependability & $\begin{array}{l}\text { relationship quality of social } \\
\text { exchange viewpoint }\end{array}$ & H3-3 & $\begin{array}{l}\text { Does dependability have a positive impact on the relationship } \\
\text { quality of the social exchange viewpoint? }\end{array}$ & yes \\
\hline customization & $\begin{array}{l}\text { relationship quality of social } \\
\text { exchange viewpoint }\end{array}$ & H3-4 & $\begin{array}{l}\text { Does customization have a positive impact on the relationship } \\
\text { quality of the social exchange viewpoint? }\end{array}$ & no \\
\hline interaction & $\begin{array}{l}\text { relationship quality of social } \\
\text { exchange viewpoint }\end{array}$ & H3-5 & $\begin{array}{l}\text { Does interaction have a positive impact on the relationship } \\
\text { quality of the social exchange viewpoint? }\end{array}$ & yes \\
\hline degree of pleasure & $\begin{array}{l}\text { relationship quality of social } \\
\text { exchange viewpoint }\end{array}$ & H3-6 & $\begin{array}{l}\text { Does degree of pleasure have a positive impact on the } \\
\text { relationship quality of the social exchange viewpoint? }\end{array}$ & yes \\
\hline matching effect & $\begin{array}{l}\text { relationship quality of social } \\
\text { exchange viewpoint }\end{array}$ & H3-7 & $\begin{array}{l}\text { Does matching effect have a positive impact on the relationship } \\
\text { quality of the social exchange viewpoint? }\end{array}$ & yes \\
\hline $\begin{array}{l}\text { quality of consultation } \\
\text { service }\end{array}$ & $\begin{array}{l}\text { relationship quality of social } \\
\text { exchange viewpoint }\end{array}$ & H3-8 & $\begin{array}{l}\text { Does quality of consultation service have a positive impact on } \\
\text { the relationship quality of the social exchange viewpoint? }\end{array}$ & yes \\
\hline
\end{tabular}

It can be seen from the regression analysis that the five dimensions of employment service encounter in "Table XII" has a positive and significant impact on relationship quality of economic exchange viewpoint, which shows that in the process of employment service encounter of job matching platform, when the above perception provided by job matching platform for the users increases, it will promote the users of platform to generate higher social relationship quality to job matching platform, which is consistent with the assumptions of this study. However, convenience, instantaneity and customization have no significant impact on the relationship quality of social exchange viewpoint in employment service encounter, so H3-1, H3-2, H3-4 are invalid. 
TABLE XIII. Hypothesis Test RESUlts OF IMPACt OF RELATIONSHIP QUALITY OF SOCIAL EXCHANGE VIEWPOINT ON POSITIVE WORD-OF-MOUTH

\begin{tabular}{|c|l|l|l|l|l|}
\hline \multicolumn{2}{|c|}{ Dimension of independent variable } & $\begin{array}{c}\text { Dimension of } \\
\text { dependent variable }\end{array}$ & $\begin{array}{c}\text { Research } \\
\text { hypothesis }\end{array}$ & \multicolumn{1}{c|}{ Content of hypothesis } \\
\hline \multirow{2}{*}{$\begin{array}{c}\text { Relationship quality of } \\
\text { social exchange viewpoint }\end{array}$} & social satisfaction & \multirow{2}{*}{ positive word-of-mouth } & H5-1 & $\begin{array}{l}\text { H5: Does the relationship quality of social } \\
\text { exchange viewpoint have a positive impact } \\
\text { on positive word-of-mouth? }\end{array}$ & yes \\
\cline { 2 - 2 } & goodwill trust & emotional commitment & & \\
\hline
\end{tabular}

It can be seen from the regression analysis in "Table XIII" that the three dimensions including social satisfaction, goodwill trust and emotional commitment of relationship quality of social exchange has a positive and significant impact on positive word-of-mouth, which shows that in the process of employment service encounter of job matching
${ }^{1 .}$ Data source: arranged by this research platform, when the relationship quality of social exchange viewpoint provided by job matching platform for the users increases, it will promote the users of platform to generate higher positive word-of-mouth to job matching platform, which is consistent with the assumptions of this study.

TABLE XIV. SUMMARY TABLE OF VERIFICATION OF HYPOTHESIS IN THIS STUDY

\begin{tabular}{|c|c|c|c|c|}
\hline $\begin{array}{c}\text { Dimension of independent } \\
\text { variable }\end{array}$ & $\begin{array}{c}\text { Dimension of } \\
\text { dependent variable }\end{array}$ & $\begin{array}{c}\text { Research } \\
\text { hypothesis }\end{array}$ & Content of hypothesis & Research results \\
\hline $\begin{array}{c}\text { Employment services } \\
\text { encounter }\end{array}$ & $\begin{array}{l}\text { relationship quality } \\
\text { of economic } \\
\text { exchange viewpoint }\end{array}$ & $\mathrm{H} 1$ & $\begin{array}{l}\text { Does the employment service encounter have a positive } \\
\text { impact on the relationship quality of the economic } \\
\text { exchange viewpoint? }\end{array}$ & yes \\
\hline $\begin{array}{c}\text { Employment services } \\
\text { encounter }\end{array}$ & $\begin{array}{l}\text { positive word-of- } \\
\text { mouth }\end{array}$ & $\mathrm{H} 2$ & $\begin{array}{l}\text { Does the employment service encounter have a positive } \\
\text { impact on the positive word-of-mouth? }\end{array}$ & no \\
\hline $\begin{array}{c}\text { Employment services } \\
\text { encounter }\end{array}$ & $\begin{array}{l}\text { relationship quality } \\
\text { of social exchange } \\
\text { viewpoint }\end{array}$ & $\mathrm{H} 3$ & $\begin{array}{l}\text { Does the employment service encounter have a positive } \\
\text { impact on the relationship quality of the social exchange } \\
\text { viewpoint? }\end{array}$ & yes \\
\hline $\begin{array}{c}\text { Relationship quality of } \\
\text { economic exchange viewpoint }\end{array}$ & $\begin{array}{l}\text { positive word-of- } \\
\text { mouth }\end{array}$ & $\mathrm{H} 4$ & $\begin{array}{l}\text { Does the relationship quality of the economic exchange } \\
\text { viewpoint have a positive impact on the positive word-of- } \\
\text { mouth? }\end{array}$ & no \\
\hline $\begin{array}{c}\text { Relationship quality of social } \\
\text { exchange viewpoint }\end{array}$ & $\begin{array}{l}\text { positive word-of- } \\
\text { mouth }\end{array}$ & H5 & $\begin{array}{l}\text { H5: Does the relationship quality of social exchange } \\
\text { viewpoint have a positive impact on positive word-of- } \\
\text { mouth? }\end{array}$ & yes \\
\hline $\begin{array}{c}\text { Interpersonal } \\
\text { Technological employment } \\
\text { services encounter }\end{array}$ & $\begin{array}{l}\text { relationship quality } \\
\text { of economic } \\
\text { exchange viewpoint }\end{array}$ & H6a & $\begin{array}{l}\text { What are the differences in the influence of service } \\
\text { encounter of different types (interpersonal, technological) } \\
\text { on the relationship quality of economic exchange } \\
\text { viewpoint? }\end{array}$ & $\begin{array}{l}\text { Do not have interference } \\
\text { effect. positive impact of } \\
\text { technological type is greater }\end{array}$ \\
\hline $\begin{array}{c}\text { Interpersonal } \\
\text { Technological employment } \\
\text { services encounter }\end{array}$ & $\begin{array}{l}\text { positive word-of- } \\
\text { mouth }\end{array}$ & H6b & $\begin{array}{l}\text { What are the differences in the influence of service } \\
\text { encounter of different types (interpersonal, technological) } \\
\text { on the positive word-of-mouth? }\end{array}$ & $\begin{array}{l}\text { Do not have interference } \\
\text { effect. positive impact of } \\
\text { technological type is greater }\end{array}$ \\
\hline $\begin{array}{c}\text { Interpersonal } \\
\text { Technological employment } \\
\text { services encounter }\end{array}$ & $\begin{array}{l}\text { relationship quality } \\
\text { of social exchange } \\
\text { viewpoint }\end{array}$ & H6c & $\begin{array}{l}\text { What are the differences in the influence of service } \\
\text { encounter of different types (interpersonal, technological) } \\
\text { on the relationship quality of social exchange viewpoint? }\end{array}$ & $\begin{array}{l}\text { Do not have interference } \\
\text { effect. positive impact of } \\
\text { technological type is greater }\end{array}$ \\
\hline
\end{tabular}

\section{CONCLUSION}

This chapter summarizes the results of statistical analysis and puts forward conclusions and suggestions.

\section{A. Impact of Employment Service Encounter on the Relationship Quality}

1) Impact of employment service encounter on the relationship quality of economic exchange viewpoint: The empirical results show that the employment service encounter does have a positive effect on the relationship quality of economic exchange viewpoint, but the results of regression analysis in SPSS show that impact of interaction and the quality of consultation service is not significant. Empirical evidence shows that in the process of the job matching platform providing employment services encounter, when the above perception provided for the job seekers increases, it will promote job seekers to generate higher economic relationship quality on the job matching platform.

2) Impact of employment service encounter on the relationship quality of social exchange viewpoint: The empirical results show that the employment service encounter has a positive effect on the relationship quality of social exchange viewpoint. It can be found from the results of regression analysis that the five dimensions including quality of consultation service, interaction, reliability, degree of pleasure and matching effect of employment service encounter do have a positive and significant impact on the relationship quality of social exchange viewpoint.

\section{B. Impact of Employment Service Encounter on the Positive Word-of-mouth}

The theoretical model of this study includes the four parts of employment service encounter, relationship quality of economic exchange viewpoint and social exchange viewpoint, and positive word-of-mouth. It adopts AMOS 20.0 to make structural model analysis to verify each 
research hypothesis, of which the results show that the observation sample and the theoretical model fit well. The empirical result of theoretical model shows that relationship quality of economic exchange viewpoint does not have a significant impact on the positive word-of-mouth, but that of social exchange viewpoint has a significant impact on the positive word-of-mouth. This theoretical model validates a major finding: "only through the relationship quality of social exchange viewpoint can employment service encounter improve the positive word-of-mouth of the intermediary."

\section{Impact of Relationship Quality on the Positive Word-of- mouth}

1) Impact of relationship quality of economic exchange viewpoint on the positive word-of-mouth: The empirical results of path analysis in AMOS show that the relationship quality of economic exchange viewpoint has no impact on the positive word-of-mouth because the standardized structure coefficient is too low. Blau (1964) proposes that the relationship quality of economic exchange viewpoint should be measured by "economic satisfaction", "competence trust" and "calculated commitment". In view of the behavioral motive of "self-interest", facing the employment service encounter, job seekers can obtain better financial reward and computational evaluation of profit from the job matching platform, which can meet the expectation of employment service, but they may not be willing to spread positive reputation.

2) Impact of Relationship Quality of Social Exchange Viewpoint on the Positive Word-of-mouth

The empirical results of path analysis in AMOS show that the relationship quality of social exchange viewpoint does have a positive impact on the positive word-of-mouth. Blau (1964) proposes that "social satisfaction", "goodwill trust" and "emotional commitment" should be used to measure the relationship quality of social exchange viewpoint. From the perspective of relationship marketing, excluding the long-term reciprocal and trust relationship established between business practices and job seekers is of course conducive to the transmission of positive word of mouth.

\section{Interference Effect of Interpersonal and Technological Employment Services Encounter}

1) Impact of interpersonal and technological employment service encounter on the relationship quality: Through the results of the odds ratio of AMOS influence path, this study points out that different types of service encounter interaction all reach the adaptive standard and have no interference effect on the relationship quality in employment service encounter. However, T-test of SPSS shows that the average value of technological employment service encounter is significantly higher than interpersonal employment services encounter. It is clear that the economic conversion awards obtained through the interface of information technology and the economic costs that break through the distance and time are the pragmatic goals that job seekers prefer to pursue.

2) Impact of Interpersonal and Technological Employment Service Encounter on the Positive Word-ofmouth: Through the results of the odds ratio of AMOS influence path, this study points out that interpersonal and technological service encounter all reach the adaptive standard and have no interference effect on the positive word-of-mouth. T-test shows that interpersonal and technological employment service encounter all have a positive impact on the positive word-of-mouth, but the average value of the technological employment services encounter is higher. When job seekers gradually think that the interface of information technology is easy to operate, and they can enjoy a high degree of autonomy to choose the time and place to accept the service, and thus achieve the benefits of customization, so their using willingness and service evaluation will be higher.

\section{REFERENCES}

[1] Arch G. Woodside, M. Wayne Delozier. Effects of Word of Mouth Advertising on Consumer Risk Taking[J]. Journal of Advertising, 1976, 5(4):12-19.

[2] Arndt. Selective processes in word-of-mouth[J]. Journal of Advertising Research,1968, 8(3).

[3] Bitner M J, Brown S W, Meuter M L. Technology infusionin service encounters[J]. Journal of the Academy of Marketing Science, 2000, 28(1): 138 .

[4] Blau P M. Exchange and power in social life[J]. American Journal of Sociology, 1964.

[5] Crosby L A, Evans K R, Cowles D. Relationship Quality inServices Selling: An Interpersonal Influence Perspective[J]. Journal of Marketing, 1990, 54(3):68-81.

[6] Das T K, Teng B S. Trust, Control, and Risk in StrategicAlliances: An Integrated Framework[J]. Organization Studies, 2016, 22(2):251283.

[7] Derbaix C, Vanhamme J. Inducing word-of-mouth byeliciting surprise - a pilot investigation[J]. Journal of Economic Psychology, 2003, 24(1):99-116.

[8] Frank J E. Word-of-Mouth Communication by theInnovator[J]. Journal of Marketing, 1969, 33(3):15-19.

[9] Fornell, C. R. \& Larcker, F. F.Structural Equation Models with Unobservable Variables and Measurement Error[J]. Journal of Marketing Research, 1981,18:39-51.

[10] Geyskens I, Steenkamp J B E M. Economic and socialsatisfaction measurement and relevance to marketing channel relationships[J]. Journal of Retailing, 2000, 76(1):11-32.

[11] Hair J F, Anderson R E, Tatham R L, et al. Multivariate Data Analysis, 5th Ed[J]. All Publications, 1998.

[12] Hennig-Thurau T, Gwinner K P, Gremler D D. Understanding relationship Marketing outcomes[J]. Journal of Service Research, 2002, 4:230-247.

[13] Holmes J H, Lett J D. Product sampling and word of mouth[J].Journal of Advertising Research, 1977, 17(5):35-40.

[14] Homans G C. Social Behavior as Exchange[J]. AmericanJournal of Sociology, 1958, 63(6):597-606.

[15] Jr J A D, Muller E. Models of New Product DiffusionThrough Advertising and Word-of-Mouth[J]. Management Science, 1978, 24(15):1568-1578. 
[16] Singh J. Voice, exit, and negative word-of-mouth behaviors: An investigation Across three service categories $[\mathrm{J}]$. Journal of the Academy of Marketing Science, 1990, 18(1):1-15.

[17] Kim W G, Cha Y. Antecedents and consequences of relationship quality in Hotel industry[J]. International Journal of Hospitality Management, 2002, 21(4):321-338.

[18] Reichheld F F, Jr S W. Zero defections: quality comes toservices.[J]. Harvard Business Review, 1990, 68(5):105.

[19] Smith A K, Bolton R N. An Experimental Investigation of Customer Reactions to Service Failure and Recovery: Paradox or Peril[J]. Journal of Service Research, 1998, 1(1):65-81.

[20] Smith R E, Vogt C A. The Effects of Integrating Advertising and Negative Word-of-Mouth Communications on Message Processing and Response[J]. Journal of Consumer Psychology, 1995, 4(2):133151.

[21] Solomon M R, Surprenant C, Czepiel J A, et al. A Role Theory Perspective on Dyadic Interactions: The Service Encounter[J]. Journal of Marketing, 1985, 49(1):99-111.

[22] Cheng Zhiyue. On the Construction of Employment Service System from Employment Service China Labor, 2000, 18(10): 20-33.

[23] Li Gengpei. Transformation and Development of Employment Service System in China in Accordance with Implementation of the Employment Insurance Law labor monthly, 2002, 1(2): 17-36.

[24] Li Jianhong. The disparity governance System and Governance contradiction: An Analysis of Employment System Reform in Taiwan Social Welfare Association of Taiwan, 2008, 6(2): 109-145.

[25] Chen Guojun. Labor research. Taibei: San Min Book Co., Ltd., 1979. 